\title{
Bacteriological and molecular study of Salmonella species associated with central nervous system manifestation in chicken flocks
}

\author{
Heba Badr ${ }^{(D)}$, Mohamed A. Soliman ${ }^{(D)}$ and Soad A. Nasef ${ }^{(D)}$ \\ Reference Laboratory for Veterinary Quality Control on Poultry Production, Animal Health Research Institute, Agricultural \\ Research Center, Nadi El-Seid Street, Dokki, Giza 12618, Egypt. \\ Corresponding author: Heba Badr, e-mail: drheba_badr@yahoo.com \\ Co-authors: MAS: mohahm@hotmail.com, SAN: dr soadnasef@yahoo.com \\ Received: 01-06-2020, Accepted: 04-09-2020, Published online: 20-10-2020
}

doi: www.doi.org/10.14202/vetworld.2020.2183-2190 How to cite this article: Badr H, Soliman MA, Nasef SA (2020) Bacteriological and molecular study of Salmonella species associated with central nervous system manifestation in chicken flocks, Veterinary World, 13(10): 2183-2190.

\begin{abstract}
Background and Aim: Salmonella species often cause systemic health problems in poultry flocks, sometimes including nervous systems manifestations. This impact of Salmonella has rarely been studied. This study aimed to define an alternative pathogenic pathway for Salmonella spp. invasion of brain tissue in chicken flocks. Brain infection produces neurological manifestations; Salmonella strains isolated from brain tissue showed the presences of two virulence genes. Confirmation of the pathway of isolates from intestinal mucosa through the blood-brain barrier was attained using experimental infections in specific pathogen-free (SPF)-day-old chicks through two routes of inoculation.

Materials and Methods: Isolation of Salmonella spp. from five chicken flocks that showed signs of the central nervous system (CNS) effects were isolated. Isolates were characterized by serotyping, and antimicrobial assays. In addition, virulence profiles were described using detection of virulence plasmid $s p v C$, and Salmonella plasmid $\operatorname{sop} B$. A pathogenicity study of isolates in specific pathogen-free (SPF)-day-old chicks through oral and intracerebral administration performed, and experimental infection in SPF embryonated chicken eggs through intra-yolk and intra-allantoic administration was investigated. Supporting histopathology and immunohistopathology against Salmonella antigen in brain tissue were performed for flock and experimental infections.

Results: Three serotypes of Salmonella were isolated from the brains of five flocks (two Salmonella Virchow, two Salmonella Kentucky, and one Salmonella Enteritidis isolates). Phage related gene sopB and plasmid-mediated operon $\operatorname{spvC}$ were identified in all isolated strains. The Salmonella strains were re-isolated and identified from the brain and internal organs of post-experimental infected chicks. Infected chicks showed nervous manifestations associated with Salmonella infection. The presence of positively stained Salmonella antigen in brain tissues indicates penetration of the blood-brain barrier by the Salmonella species.
\end{abstract}

Conclusion: Our results indicate that some virulent systemic strains of Salmonella spp. can induce CNS manifestations in chicken hosts.

Keywords: chicken, experimental study, CNS manifestations, polymerase chain reaction, Salmonella spp., virulence genes.

\section{Introduction}

The Salmonella genus includes thousands of serovars cause disease in many host species [1-3]. The genus is classified into three divisions according to host adaptation and invasiveness. Invasive serovars, such as Salmonella Pullorum, Salmonella Gallinarum in poultry, and Salmonella Typhi, cause human disease. The second group consists of approximately ten serovars that cause an invasive infection in poultry and may cause human infection. At present, the most important serovars are Salmonella Enteritidis, Salmonella Typhimurium, Salmonella Hadar,

Copyright: Badr, et al. Open Access. This article is distributed under the terms of the Creative Commons Attribution 4.0 International License (http://creativecommons.org/licenses/by/4.0/), which permits unrestricted use, distribution, and reproduction in any medium, provided you give appropriate credit to the original author(s) and the source, provide a link to the Creative Commons license, and indicate if changes were made. The Creative Commons Public Domain Dedication waiver (http://creativecommons.org/ publicdomain/zero/1.0/) applies to the data made available in this article, unless otherwise stated.
Salmonella Heidelberg, S. Saintpaul, and Salmonella Infantis. The third group consists of non-host-adapted and non-invasive serovars [4-9].

Non-typhoid Salmonella infections are associated with 2500 serovars that cause gastroenteritis in avian, bovine, and porcine hosts; the most common species $S$. Typhimurium and $S$. Enteritidis $[10,11]$. Intestinal disease occurs after a short incubation period of 12-72 h [12]. Limited spread of brain disease reflects an inability to overcome host defenses outside the intestinal mucosa. Still, studies in humans and mice show intermittent neurological abnormalities that permit the study of brain infection $[13,14]$.

Mechanisms for gaining access to the central nervous system (CNS) from the intestinal mucosa by Salmonella are not well known, yet such invasion remains a matter of concern. An appropriate animal model is lacking, although an experiment with rabbits using $S$. Enteritidis reported meningitis [15]. Other studies have addressed pathways of transfer of 
intracellular pathogens to the CNS [16,17]. Modes of translocation could be intercellular, trans-cellular, cell-mediated, or other novel mechanisms [18].

Virulence plasmids are identified by a $7.8 \mathrm{~kb}$ region referred to as $s p v$ (Salmonella plasmid virulence), which contains five genes, designated $s p v R, A, B, C$, and $D$ [19]. The spv region promotes the rapid growth and survival of Salmonella spp. within the host cells, and it is important for systemic infection [20]. Salmonella plasmid virulence is essential for bacterial multiplication within the reticuloendothelial system of hosts [21].

The virulence of Salmonella spp. and their interaction with the host are complex and involve virulence factors to counter host defenses. Molecular assays for virulence genes of $S$. Enteritidis isolates from poultry in Brazil using nine genes ( $\operatorname{lpf} A$, agfA, sefA, invA, hilA, avrA, sopE, sivH, and spvC) were detected by Pilla and Tang [22]. Besides, Mezal et al. [23] indicate a strong distribution of $\operatorname{sop} B$ conserved genes among only a few serovars of Salmonella (Enteritidis, Gallinarum, and Virchow); the presence of $\operatorname{sop} B$ genes in Salmonella enhances invasion of epithelial cells, which may indicate their importance in pathogenesis.

Neurological manifestations induced by Salmonella spp. have rarely been reported in chicken flocks. Salmonella enterica arizonae was reported to produce neurological manifestations, with peritonitis, gastroenteritis, and hepatitis in turkey poults [24]. This study is the only published data on the issue to date, to the best of our knowledge.

The significance of the current study is the reinforcement of the importance of neurological disorders caused by Salmonella infection. This study aimed to define an alternative pathogenic pathway for Salmonella spp. invasion of brain tissue in chicken flocks. Brain infection produces neurological manifestations; Salmonella strains isolated from brain tissue showed the presences of two virulence genes. Confirmation of the pathway of isolates from intestinal mucosa through the blood-brain barrier was attained using experimental infections in specific pathogen-free (SPF)-day-old chicks through two routes of inoculation.

\section{Materials and Methods}

\section{Ethical approval}

Treatment of birds in experimental infections was in accordance with the regulations for the care and husbandry of experimental animals and approved by the Animal Care Committee of the Animal Health Research Institute, Giza, Egypt.

\section{Study period and location}

The study was performed between November 2017 and December 2019 at the Reference Laboratory for Veterinary Quality Control on Poultry Production.

\section{Collection of samples}

Brain samples were aseptically collected from freshly dead or euthanized diseased broiler chickens from five Cobb flocks. Birds selected showed CNS manifestations-lying down with stretched legs, ataxia, and infrequent tremor. Age of infected birds varied from 1 to 34 days.

\section{Isolation and identification of Salmonella spp.}

Bacteria were isolated and identified, as previously described [25]. Briefly, pre-enrichment of brain tissue used Buffer Peptone Water (Oxoid ${ }^{\circledR}$, UK) incubated at $37^{\circ} \mathrm{C}$ for $16-18 \mathrm{~h}$. One-tenth $\mathrm{mL}$ of pre-enrichment medium was transferred to Modified Semisolid Rappaport-Vassiliadis medium $\left(\mathrm{LabM}^{\circledR}\right.$, UK) and incubated at $41.5^{\circ} \mathrm{C}$ for $24 \mathrm{~h}$. Furthermore, $1 \mathrm{~mL}$ was transferred to MKTTn broth $\left(\mathrm{LabM}^{\circledR}, \mathrm{UK}\right)$ and incubated aerobically for $24 \mathrm{~h}$. The samples were then streaked onto XLD (LabM $\left.{ }^{\circledR}, \mathrm{UK}\right)$ and SS (Oxoid $\left.{ }^{\circledR}, \mathrm{UK}\right)$ agar plates and incubated at $37^{\circ} \mathrm{C}$ for $24 \mathrm{~h}$, aerobically. Typical colonies were identified by biochemical tests (Urea agar, Triple sugar iron, and Lysin iron) (Oxoid $\left.{ }^{\circledR}, \mathrm{UK}\right)$.

\section{Serotyping of isolated Salmonella spp.}

Serotyping was accomplished as previously described [26], followed by the reading of Salmonella species using the Kauffman-White scheme [27] with Salmonella antisera (Sifin ${ }^{\circledR}$, Japan).

\section{Antimicrobial sensitivity test for Salmonella strains}

The antibiogram of Salmonella isolates used disk-diffusion tests as previously described [28] against 17 antibiotics $\left(\mathrm{Oxoid}^{\circledR}\right.$, UK) (ampicillin, chloramphenicol, ciprofloxacin, clindamycin, colistin sulfate, doxycycline, florfenicol, fosfomycin, gentamicin, levofloxacin, lincomycin, nalidixic acid, neomycin, norfloxacin, streptomycin, tetracycline, and trimethoprim-sulfamethoxazole). Assay results were interpreted according to CLSI/NCCLS [29].

\section{Molecular detection of virulence genes sopB and spvC}

A conventional polymerase chain reaction (PCR) assay was performed for detection of virulence genes. DNA was extracted from isolates using a QIAamp DNA Mini Kit following kit instructions, (Qiagen, Germany, GmbH) catalog no. 51304. PCR used extracted DNA using specific primers (Metabion, Germany) [30,31] to amplify virulence genes (sopB and $s p v C$ ) (Table-1) using PCR Master Mix (Takara,

Table-1: Primers sequence, target genes, amplified sizes, and annealing condition.

\begin{tabular}{llccc}
\hline Target gene & Primers sequences & Amplified product & Annealing & References \\
\hline sop $B$ & F- TCAGAAGRCGTCTAACCACTC & $517 \mathrm{bp}$ & $58^{\circ} \mathrm{C}$ & {$[30]$} \\
spvC & R- TACCGTCCTCATGCACACTC & & $40 \mathrm{~s}$ & \\
& F- ACCAGAGACATTGCCTTCC & $467 \mathrm{bp}$ & $58^{\circ} \mathrm{C}$ & {$[31]$} \\
\hline
\end{tabular}


Japan). The amplification was performed in a Biometra T3 thermal cycler. The PCR products were separated by electrophoresis on $1 \%$ agarose gel according to Sambrook et al. [32] (Applichem, Germany) in 1× TBE buffer atroom temperature $\left(24^{\circ} \mathrm{C}\right)$ using a gradient of $5 \mathrm{~V} / \mathrm{cm}$. Fifteen $\mu \mathrm{L}$ of PCR product was loaded in each gel slot. A 100 bp DNA Ladder (Qiagen, Germany) was used to determine fragment sizes. The gel was photographed with a gel documentation system (Alpha Innotech, Biometra, Germany).

\section{Experimental study}

\section{Preparation of bacterial inoculums}

Five Salmonella serotypes (two isolates $S$. Virchow, two $S$. Kentucky, and one $S$. Enteritidis) were prepared according to Osman et al. [33] from frozen stocks by sub-culturing into Buffered peptone water (Oxoid ${ }^{\circledR}$, UK) and incubating at $37^{\circ} \mathrm{C}$ for 24 $\mathrm{h}$ aerobically. A loopful was streaked onto XLD agar plate $\left(\mathrm{LabM}^{\circledR}, \mathrm{UK}\right)$ and incubated overnight at $37^{\circ} \mathrm{C}$, aerobically. A colonywas then inoculated into Tryptic Soy Broth (TSB, Merck ${ }^{\circledR}$, Germany) and incubated overnight at $37^{\circ} \mathrm{C}$ aerobically. The overnight culture in TSB was serially diluted in sterile normal saline to reach an inoculum of $10^{6} \mathrm{CFU} / \mathrm{ml}$ for oral dosing and $10^{4}$ (for intracerebral and embryonated chicken eggs [ECE]). CFU estimates were confirmed by colony counting on Tryptic Soya Agar plates.

\section{Pathogenicity study on one-day-old chicks}

The experiment was designed to examine the pathogenicity of five Salmonella isolates in $110 \mathrm{SPF}$ chicks - ten chicks for each group (Table-2). Two routes of inoculation (oral and intracerebral) were used. The chicks were divided into 11 groups of ten chicks each: One control group, and two trial groups for each isolate, one for oral, and one for intracerebral inoculation). Ten SPF day-old chicks per group were housed in separate controlled biosafety cages at the RLQP experiment animal house. A day before infection samples were collected (pooled fecal samples and internal organs of 1-day-old chicks) and tested to confirm the absence of Salmonella. Birds were kept off feed for $12 \mathrm{~h}$ before inoculation to reduce crop bulk, thus speeding flushing of inocula.

\section{Oral pathogenicity}

Infection dose was $0.1 \mathrm{~mL}$ introduced orally for each animal in each oral exposure group $\left(1 \times 10^{5} \mathrm{CFU} / \mathrm{mL}\right)$ for observation of morbidity and mortality. Birds were observed for 15 days. Birds had access to feed and water ad libitum with $24 \mathrm{~h}$ of light daily according to Osman et al. [33]. Euthanasia of SPF chicks and re-isolation of Salmonella from internal organs and brain were performed.

\section{Intracerebral pathogenicity}

SPF-day-old chicks were inoculated intracerebrally with $0.1 \mathrm{~mL}$ (final concentration $1 \times 10^{3}$ $\mathrm{CFU} / \mathrm{mL}$ ) according to Bryan and Scheld [15] to monitor strain pathogenicity. Later, re-isolation of Salmonella serotypes from the brain and internal organs was used to assess transmission through the blood-brain barrier. The level of pathogenicity of an isolate was estimated by monitoring clinical signs and mortality rate.

\section{Inoculation of SPF fertile eggs}

One hundred and ten SPF ECE were candled for intra-yolk inoculation of $1 \times 10^{3} \mathrm{CFU} / \mathrm{mL}$ at day $6(50$ eggs), intra-allantoic at 11 day (50 eggs), and ten SPF eggs were used as negative control; each of the five Salmonella strains was inoculated twice into 10 SPF eggs with $0.1 \mathrm{~mL}$ of $1 \times 10^{4} \mathrm{CFU} / \mathrm{mL}$ of bacterial culture (intrayolk and intra-allantoic routes). The results were used to identify transmission Salmonella serotypes from parent, and persistence of such infection through hatching.

\section{Immunohistopathology}

Chicken brains were collected and fixed in $10 \%$ formalin. Following dehydration, tissues were embedded in paraffin and sections using a microtome. Sections were deparaffinized in xylene and rehydrated through a series of decreasing alcohol solutions and finally immersed in distilled water for $5 \mathrm{~min}$. Some sections were stained with hematoxylin-eosin [34], while others were processed for staining with antibody against Salmonella somatic $\mathrm{O}$ antigen using a primary rabbit anti-Salmonella antibody (ab35156) and Secondary-Goat Anti-Rabbit IgG H\&L (HRP) (ab205718). Staining with DAB brown was used to visualize bacterial antigen microscopically [35].

\section{Results}

\section{Isolation, identification, and serogrouping}

Examination of collected brain samples for Salmonella isolation identified five isolates of Salmonella spp. Serotypes for these isolates were $S$. Virchow, two strains $(\mathrm{O} 6,7,14 ; \mathrm{r} ; 1,2), S$. Kentucky, two strains $\left(\mathrm{O} 8,20 ; \mathrm{i} ; \mathrm{Z}_{6}\right)$, and $S$. Enteritidis, one strain $(\mathrm{O} 1,9,12$; g, m;--).

Table-2: Groups of Pathogenicity study on 1-day-old chicks.

\begin{tabular}{llccc}
\hline Serotypes & $\begin{array}{l}\text { Number of } \\
\text { groups }\end{array}$ & $\begin{array}{c}\text { Number of SPF } \\
\text { chicks (orally) }\end{array}$ & $\begin{array}{c}\text { Number of SPF chicks } \\
\text { (intra cerebral) }\end{array}$ & $\begin{array}{c}\text { Negative } \\
\text { control }\end{array}$ \\
\hline Salmonella Virchow & Gr. No. 1 & 10 & 10 & 10 \\
Salmonella Kentucky & Gr. No. 2 & 10 & 10 & 10 \\
Salmonella Enteritidis & Gr. No. 3 & 10 & 10 & 10 \\
Total=110 & Gr. No. 4 & 10 & 50 & 10 \\
\hline
\end{tabular}




\section{Antimicrobial sensitivity test for Salmonella strains}

All strains were resistant to clindamycin and lincomycin while, four of five were resistant to ampicillin, gentamycin, nalidixic acid, streptomycin, tetracycline, and trimethoprim-sulfamethoxazole and three of five were resistant to doxycycline and norfloxacin. In contrast, all strains were highly susceptible to colistin sulfate and fosfomycin and three of five were sensitive to ciprofloxacin and levofloxacin (Table-3).

\section{Molecular detection of virulence genes}

Isolated strains of Salmonella all showed the presence of phage related gene $\operatorname{sop} B$ and the plasmid-mediated operon spvC (Figure-1a and b).

\section{Pathogenicity study}

SPF-day-old chicks were inoculated by two routes. Chicks administered bacteria orally showed different mortality and morbidity rates. Chicks inoculated with $S$. Virchow showed $40 \%$ mortality in one group and $0 \%$ in the second group. However, chicks in both groups exhibited diarrhea after 1 week of infection along with closed eye and difficulty breathing. The two groups of chicks inoculated with $S$. Kentucky showed 20\% mortality and the same signs as chick inoculated with $S$. Virchow. No mortality was seen in chicks inoculated with $S$. Enteritidis; these chicks again showed diarrhea, closed eye, and difficulty breathing.

Chicks administered by intracerebral injection showed $100 \%$ mortality before $24 \mathrm{~h}$. Chicks struggled and stretched legs and wings before death. Severe congestion of blood vessels of skull and internal organs, with omphalitis, was noted (Table-4).

After 2 weeks postmortem examination of euthanized surviving chicks from oral route inoculation showed congestion of muscle and internal organs, ballooning of intestine-especially ceca-unabsorbed yolk sac, and congestion of the skull region and, in varying degrees, of the brain. The re-isolation of Salmonella from organs, intestine, and brain was successful for all groups of chicks and for all serovars.

SPF ECE were also inoculated through two routes. Intra-yolk inoculation at 6 days of age caused

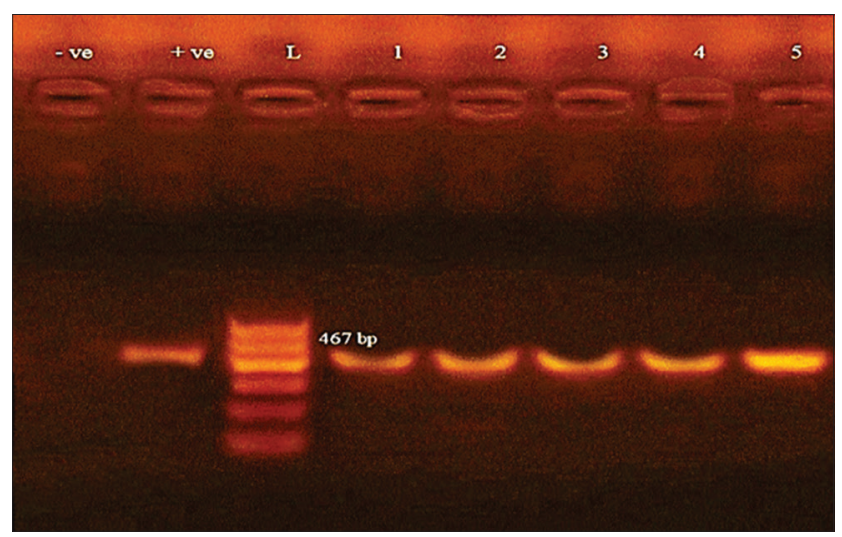

Figure-1a: Agarose gel electrophoresis showing amplification of $467 \mathrm{bp}$ fragments using PCR was performed with primer specific for $s p v C$ gene. Lane (1-5) shows the positive amplification of five isolates. L: Ladder (100-600). +ve: Positive control and -ve: Negative control.

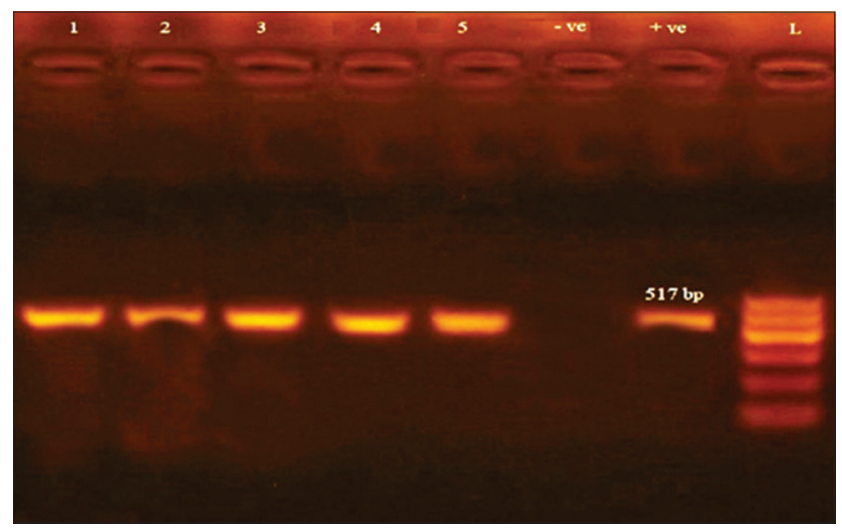

Figure-1b: Agarose gel electrophoresis showing amplification of $517 \mathrm{bp}$ fragments using PCR was performed with primer specific for sopB gene. Lane (1-5) shows the positive amplification of five isolates. L: Ladder (100-600). +ve: Positive control and -ve: Negative control.

Table-3: Results of antimicrobial sensitivity tests.

\begin{tabular}{lccc}
\hline Antimicrobial discs & \multicolumn{2}{c}{ Salmonella spp. isolates interpretation (n=5) } \\
\cline { 2 - 4 } & Sensitivity (\%) & Intermediate (\%) & Resistance (\%) \\
\hline Ampicillin & $1(20)$ & 0 & $4(80)$ \\
Chloramphenicol & $2(40)$ & $1(20)$ & $2(40)$ \\
Ciprofloxacin & $3(60)$ & 0 & $2(40)$ \\
Clindamycin & 0 & 0 & $5(100)$ \\
Colistin sulfate & $5(100)$ & 0 & 0 \\
Doxycycline & $1(20)$ & $1(20)$ & $3(60)$ \\
Florfenicol & $2(40)$ & $1(20)$ & $2(40)$ \\
Fosfomycin & $5(100)$ & 0 & 0 \\
Gentamicin & $1(20)$ & 0 & $4(80)$ \\
Levofloxacin & $3(60)$ & $2(40)$ & 0 \\
Lincomycin & 0 & 0 & $5(100)$ \\
Nalidixic acid & $1(20)$ & 0 & $4(80)$ \\
Neomycin & $1(20)$ & $2(40)$ & $2(40)$ \\
Norfloxacin & $2(40)$ & 0 & $3(60)$ \\
Streptomycin & $1(20)$ & 0 & $4(80)$ \\
Tetracycline & $1(20)$ & 0 & $4(80)$ \\
Trimethoprim-sulfamethoxazole & $1(20)$ & & $4(80)$ \\
\hline
\end{tabular}


Table-4: Results of Salmonella isolates from bacteriological examination from collected brain tissue and mortality rate in pathogenicity study.

\begin{tabular}{lccc}
\hline $\begin{array}{l}\text { Serotypes/(Number of } \\
\text { isolates) }\end{array}$ & $\begin{array}{l}\text { Number } \\
\text { of group }\end{array}$ & $\begin{array}{c}\text { Mortality rate by oral route } \\
\text { \% (Number of dead/total) }\end{array}$ & $\begin{array}{c}\text { Mortality rate in intra-cerebral } \\
\text { route \% (Number of dead/total) }\end{array}$ \\
\hline Salmonella Virchow (2) & Gr. No. 1 & $40(4 / 10)$ & $100(10 / 10)$ \\
& Gr. No. & $0(0 / 10)$ & $100(10 / 10)$ \\
Salmonella Kentucky (2) & Gr. No. 3 & $20(2 / 10)$ & $100(10 / 10)$ \\
Salmonella Enteritidis (1) & Gr. No. 4 & $20(2 / 10)$ & $100(10 / 10)$ \\
& Gr. No. 5 & $0(0 / 10)$ & $100(10 / 10)$ \\
\hline
\end{tabular}

$100 \%$ mortality after $24 \mathrm{~h}$ for one $S$. Kentucky serovar, while other serovars (two $S$. Virchow, one $S$. Kentucky, and one $S$. Enteritidis) showed $100 \%$ mortality 5 days after inoculation. Congestion of the embryo and yolk sac was found on examination of dead embryos.

Intra-allantoic inoculation of $S$. Virchow at 11 days of age showed $50 \%$ mortality after $24 \mathrm{~h}, 90 \%$ after 3 days, and $100 \%$ after 10 days. S. Kentucky showed $100 \%$ mortality after 3 days. $S$. Enteritidis caused $100 \%$ mortality after $24 \mathrm{~h}$. severe congestion in embryo and yolk sac was observed on examination of dead embryos. The re-isolation of Salmonella from embryo and yolk sacs was successful for all strains.

\section{Histopathology}

Histopathological examination showed focal mononuclear cell aggregations in cerebral tissue in naturally infected birds (Figure-2a). Necrotic foci with cellular debris, surrounded by macrophages, vacuolation and microgliosis, were observed after oral route inoculation with $S$. Virchow (Figure-2b).

\section{Immunohistopathology}

Antibodies specific to Salmonella O antigen showed the presence of positively stained bacterial antigen in the cortex and medulla, consistent with findings in naturally infected chickens (Figure-3a), in experimental intracerebral infection with $S$. Virchow (Figure-3b) and in oral infection with $S$. Virchow (Figure-3c).

\section{Discussion}

Salmonella is a relatively common hazard in developing countries, though seldom seen in developed countries [36,37]. Brain infection is an unusual consequence of salmonellosis [38]. In many species of animals, Salmonella meningitis is a major cause of death and brain damage and is correlated with a particularly poor prognosis $[39,40]$. Salmonella spp. are the most common cause of death attributed to bacterial meningitis [41].

We seldom find studies on Salmonella isolated from poultry brain. Salmonella $\mathrm{spp}$. is the leading cause of bacterial meningitis in children, account for almost $13 \%$ of childhood bacterial meningitis cases $[42,43]$. Isolated Salmonella from meningitis cases is serotyped as $S$. Typhimurium, $S$. Enteritidis, $S$. Panama, $S$. Bredeney, $S$. Infantis, $S$. Virchow, $S$. Sandiego, and $S$. Newport [44]. A report from the Centers for Disease

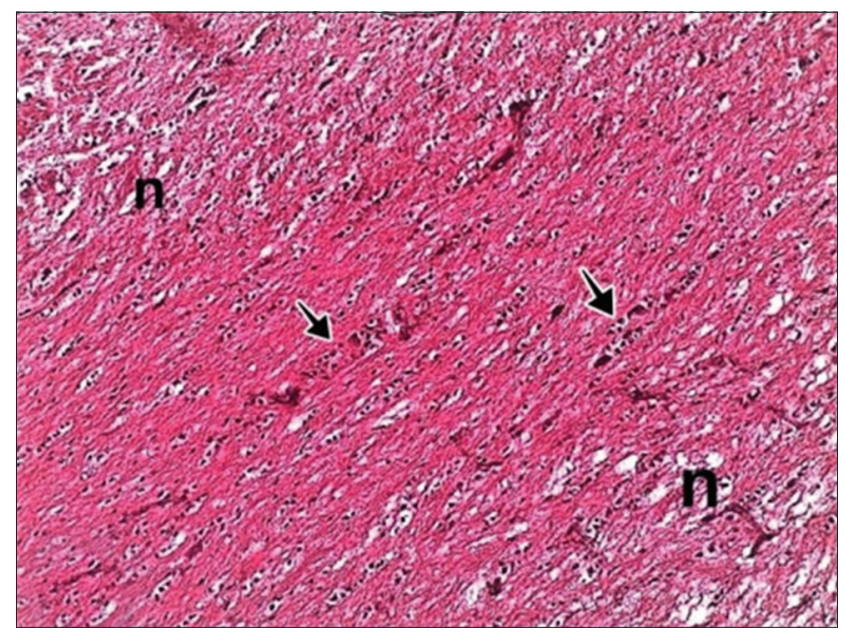

Figure-2a: Brain showed focal necrosis ( $n$ ) with accumulation of mononuclear cells (arrow) H and E, 200x.

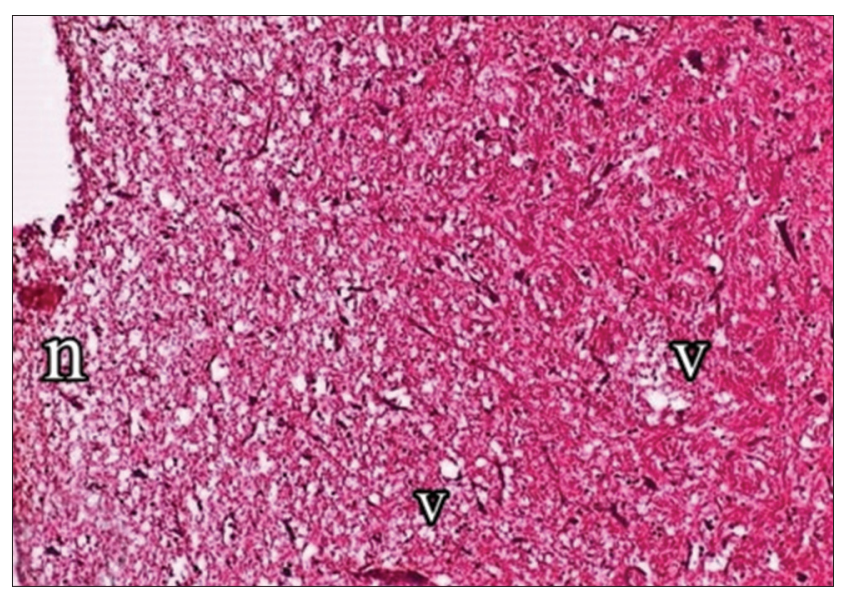

Figure-2b: Brain showed focal necrosis $(n)$ with vacuolation (v) in cerebrum. $\mathrm{H}$ and $\mathrm{E}, 200 \times$.

Control cited by Wilson and Feldman [45] indicates that $S$. Heidelberg and $S$. Saintpaul accounted for most salmonellae isolated from the cerebrospinal fluid of patients in the USA.

In the current study, bacterial isolation from collected brain samples of broilers suffering from CNS manifestation at age $\sim 15$ days old showed five isolates of Salmonella spp. Two isolates were identified and serotyped as $S$. Virchow, two isolates $S$. Kentucky, and one isolate of $S$. Enteritidis. Other cases show evidence of Salmonella meningitis in several species, but not in poultry $[46,47]$. However, Salmonella isolation was absent in brains of examined broiler chicken flocks in the Kafr El- Sheikh Province in northern Egypt [48]. 


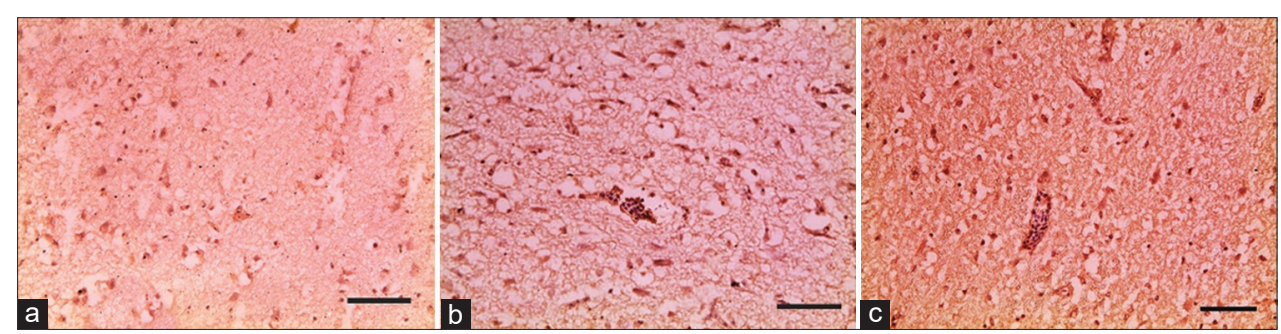

Figure-3: Brain sections showed positive reaction of Salmonella LPS antigen of dark brown spots in natural infected chickens (a), in intracerebral route of experimental infected chickens (b) and in oral route (c), scale bar 200 $\mu \mathrm{m}$.

Antimicrobial therapy is an important tool in reducing the enormous losses in the poultry industry caused by Salmonella infections. However, resistance to existing antimicrobials is widespread and of concern to poultry veterinarians [49]. Administration of antimicrobials to chickens at therapeutic and sub-therapeutic levels has been an integral part of poultry production, and this practice plays a role in encouraging antibiotic-resistant organisms. Once established, resistant organisms can spread from farm to humans through consumption of contaminated food [50]. Antimicrobial drug use in livestock production is implicated in the development and dissemination of drug resistance to public health [51,52]. Examination of five Salmonella strains for antibiotic resistance revealed high resistance in all strains to several widely used drugs and two or three of the of five strains were resistant to doxycycline and norfloxacin to most of the remaining antibacterials. High sensitivity in all strains was found only for colistin sulfate and fosfomycin among tested agents.

Mendonça et al. [53], found low levels of resistance for sulfonamides (75.8\%) and nitrofurantoin $(52.8 \%)$, tetracycline $(15.4 \%)$, streptomycin $(7.7 \%)$, nalidixic acid $(7.7 \%)$, gentamicin $(5.5 \%)$, norfloxacin (3.3\%), trimethoprim $(3.3 \%)$, cefalotin $(2.2 \%)$, ampicillin $(1.1 \%)$, and chloramphenicol (1.1\%). Tolerance to ciprofloxacin was not observed, suggesting a slow progression to resistance. This problem raises concerned among scientists that Salmonella meningitis would see a high rate of medication failure, a high rate of relapse, and significant neurological sequelae Herold et al. [54]. In the current study, the application of molecular identification of virulence genes for isolated strains that all strains showed the presence of phage related gene sop $B$ and the plasmid-mediated operon $s p v C$. Connor et al. [55] showed that the presence of the $s o p B$ gene in isolated strains of $S$. Enteritidis and $S$. Typhimurium has zoonotic potential.

The $\operatorname{sop} B$ gene is encoded in SPI-1 and is identified in isolates involved in major epidemics; $\operatorname{sop} B$ has therefore been identified as a key to the emergence of epidemic strains [56]. All $S$. Enteritidis isolated in another study from different species, human, chicken, and egg houses, report positive results for $\operatorname{sop} B$. This factor is likely to be critical for pathogenesis [57].

Orally inoculated in day-old-SPF chicks in our study showed different mortality $(0-40 \%)$ with different morbidity rates. Intracerebral inoculation showed $100 \%$ mortality for all Salmonella serotypes before $24 \mathrm{~h}$. Chick struggled with stretched legs and wings before death. Re-isolation of Salmonella from the lungs, stomach, and brain from all groups of chicks shows that salmonellae had passed through the bloodbrain barrier, from organs to the brain and vice versa.

Whether Salmonella invades the CNS primarily as intracellular bacteria is not known [58]. Pathogenesis is affected not only by the dosage and route of inoculation but also by the genetic background and immune state of the host $[59,60]$.

However, inoculation of SPF embryonic chicken eggs through intra-yolk and intra-allantoic injection caused $100 \%$ mortality at times ranging from $24 \mathrm{~h}$ to 5 days. All ECE infections with isolated Salmonella spp. induced lack of hatchability.

To the best of our knowledge, studies on infection with Salmonella in the chicken brain are limited, but Salmonella spp. are extensively studied in mice. An important role for Salmonella pathogenicity island (SPI) 1 and outer membrane protein A genes enable blood-brain barrier penetration [14]. Furthermore, behavioral abnormalities in infected mice show neurological signs of illness (twirling, and loss of motor coordination) associated with numerous bacteria in brain, spleen, and liver. Others demonstrated that oral infection of mice with $S$. enterica serovar Typhimurium resulted in meningitis and brain infection [61].

Limited studies that record CNS manifestation in turkey poults due to Salmonella enterica arizonae infection [24] associated with gastroenteritis and hepatitis. We conclude that both presence of $\operatorname{sop} B$ and $s p v C$ virulent genes for isolated Salmonella strains and positive reaction obtained from the use of specific antibodies to Salmonella LPS antigen in neuronal tissue provide strong evidence of the invasiveness of isolated pathogenic Salmonella. Further, results highlight that some Salmonella spp. serovars cross the blood-brain barrier that is considered an alternative pathogenic pathway.

\section{Conclusion}

We conclude that certain serovars of Salmonella spp. have the ability to induce adverse CNS signs in chickens after crossing the blood-brain barrier. Further, investigation is needed using other serovars to confirm the alternative infection pathway. 


\section{Authors' Contributions}

HB and SAN designed the study. HB and MAS performed the experiments, processed the experimental data and performed the validation analysis. $\mathrm{HB}$ and MAS analyzed the results and drafted the manuscript. $\mathrm{HB}$ and MAS revised and finalized the manuscript for submission. All authors read and approved the final manuscript.

\section{Acknowledgments}

We would like to thank the Reference Laboratory for Veterinary Quality Control on Poultry Production (RLQP) for providing the infrastructure for conducting the study. The authors did not receive any funds for this study.

\section{Competing Interests}

The authors declare that they have no competing interests.

\section{Publisher's Note}

Veterinary World remains neutral with regard to jurisdictional claims in published institutional affiliation.

\section{References}

1. Eng, S.K., Pusparajah, P., Mutalib, N.S.A., Ser, H.L., Chan, K.G. and Lee, L.H. (2015) Salmonella: A review on pathogenesis, epidemiology and antibiotic resistance. Front. Life Sci., 8(3): 284-293.

2. Crump, J.A., Sjölund-Karlsson, M., Gordon, M.A. and Parry, C.M. (2015) Epidemiology, clinical presentation, laboratory diagnosis, antimicrobial resistance, and antimicrobial management of invasive Salmonella infections. Clin. Microbiol. Rev., 28(4): 901-937.

3. Jajere, S.M. (2019) A review of Salmonella enterica with particular focus on the pathogenicity and virulence factors, host specificity and antimicrobial resistance including multidrug resistance. Vet. World., 12(4): 504-521.

4. OIE. (1996) Fowl typhoid and Pullorum disease. In: Manual of Standards for Diagnostic Tests and Vaccines. World Organization for Animal Health, Paris, France, p532-538.

5. Kariuki, S., Gordon, M.A., Feasey, N. and Parry, C.M. (2015) Antimicrobial resistance and management of invasive Salmonella disease. Vaccine, 33(3): C21-C29.

6. Kapperud, G., Stenwig, H. and Lassen, J. (1998) Epidemiology of Salmonella Typhimurium O: 4-12 infection in Norway evidence of transmission from an avian wildlife reservoir. Am. J. Epidemiol., 147(8): 774-782.

7. Lu, Y., Zhao, H., Sun, J., Liu, Y., Zhou, X., Beier, R.C., Wu, G. and Hou, X. (2014) Characterization of multidrug-resistant Salmonella enterica serovars Indiana and Enteritidis from chickens in Eastern China. PLoS One, 9(5): e96050.

8. Coble, D., Sandford, E., Ji, T., Abernathy, J., Fleming, D. and Zhou, H. (2013) Impacts of Salmonella Enteritidis infection on liver transcriptome in broilers. Genesis, 51(5): 357-364

9. Yeh, J.C., Chen, C.L., Chiou, C.S., Lo, D.Y., Cheng, J.C. and Kuo, H.C. (2018) Comparison of prevalence, phenotype, and antimicrobial resistance of Salmonella serovars isolated from turkeys in Taiwan. Poult. Sci., 97(1): 279-288.

10. Santos, R.L., Zhang, S., Tsolis, R.M., Kingsley, R.A., Adams, L.G. and Baumler, A.J. (2001) Animal models of Salmonella infections: Enteritis versus typhoid fever. Microb. Infect., 3(14-15): 1355-1344.
11. Lahiri, A., Lahiri, A., Iyer, N., Das, P. and Chakravortty, D. (2010) Visiting the cell biology of Salmonella infection. Microb. Infect., 12(11): 809-818.

12. Raffatellu, M., Wilson, R.P., Winter, S.E. and Baumler, A.J. (2008) Clinical pathogenesis of typhoid fever. JIDC, 2(4): 260-266.

13. Dewan, P., Pooniya, V., Kaushik, J.S., Gomber, S. and Singhal, S. (2009) Isolated cerebellar ataxia: An early neurological complication of enteric fever. Ann. Trop. Paediatr. 29(3): 217-219.

14. Chaudhuri, D., Chowdhury, A.R., Biswas, B. and Chakravortty, D. (2018) Salmonella Typhimurium infection leads to colonization of the mouse brain and is not completely cured with antibiotics. Front. Microbiol., 9(1632): $1-12$.

15. Bryan, J.P. and Scheld, W.M. (1992) Therapy of experimental meningitis due to Salmonella Enteritidis. Antimicrob. Agents chemother., 36(5): 949-954.

16. Huang, S.H. and Jong, A.Y. (2001) Cellular mechanisms of microbial proteins contributing to invasion of the bloodbrain barrier. Cell Microbiol., 3(5): 277-287.

17. Koedel, U., Scheld, W.M. and Pfister, H.W. (2002) Pathogenesis and pathophysiology of pneumococcal meningitis. Lancet Infect. Dis., 2(12): 721-736.

18. Kim, K.S. (2012) Current concepts on the pathogenesis of Escherichia coli meningitis: Implications for therapy and prevention. Curr. Opin. Infect. Dis., 25(3): 273-278.

19. McGill, F., Heyderman, R.S., Panagiotou, S., Tunkel, A.R. and Solomon, T. (2016) Acute bacterial meningitis in adults. Lancet, 388(10063): 3036-3047.

20. Andesfha, E., Indrawati, A., Mayasari, N.L.P., Rahayuningtyas, I. and Jusa, I. (2019) Detection of Salmonella pathogenicity island and Salmonella plasmid virulence genes in Salmonella Enteritidis originated from layer and broiler farms in Java Island. J. Adv. Vet. Anim. Res., 6(3): 384-393.

21. Passaris, I., Cambré, A., Govers, S.K. and Aertsen, A. (2018) Bimodal expression of the Salmonella Typhimurium spv Operon. Genetics, 210(2): 621-635.

22. Pilla, G. and Tang, C.M. (2018) Going around in circles: Virulence plasmids in enteric pathogens. Nat. Rev. Microbiol., 16(8): 484-495.

23. Mezal, E.H., Sabol, A., Khan, M.A., Ali, N., Stefanova, R. and Khan, A.A. (2014) Isolation and molecular characterization of Salmonella enterica serovar Enteritidis from poultry house and clinical samples during 2010. Food Microbiol., 38(2014): 67-74.

24. Shivaprasad, H.L., Cortes, P. and Crespo, R. (2006) Otitis interna (labyrinthitis) associated with Salmonella enterica arizonae in turkey poults. Avian Dis., 50(1): 135-138.

25. International Organization for Standardization. ISO 6579. (2017) Microbiology of the Food Chain-horizontal Method for the Detection, Enumeration and Serotyping of Salmonella-Part 1: Detection of Salmonella spp. International Standards Organization, Geneva.

26. International Organization for Standardization. ISO 6579. (2014) Microbiology of Food and Animal Feeding Stuffshorizontal Method for the Detection of Salmonella Part 3. International Standards Organization, Geneva.

27. Grimont, P.A.D. and Weill, F.X. (2007) Antigenic formulas of the Salmonella Serovars. $9^{\text {th }}$ ed. WHO Collaborating Center for Reference and Research on Salmonella, Paris.

28. Koneman, E.W., Allen, S.D., Janda, W.M., Schreckenberger, P.C. and Winn, W.C. (1997) Diagnostic Microbiology. $5^{\text {th }}$ ed., Ch. 1. Saunders, Elsevier, Philadelphia, PA, New York.

29. Clinical and Laboratory Standards Institute. (2017) Performance Standards for Antimicrobial Susceptibility Testing. $27^{\text {th }}$ Informational Supplement Document M100-S27. Vol. 37. Clinical and Laboratory Standards Institute, Wayne.

30. Thung, T.Y., Radu, S., Mahyudin, N.A., Rukayadi, Y., 
Zakaria, Z., Mazlan, N., Tan, B.H., Lee, E., Yeoh, S.L., Chin, Y.Z., Tan, C.W., Kuan, C.H., Basri, D.F. and Wan Mohamed Radzi, C.W.J. (2018) Prevalence, virulence genes and antimicrobial resistance profiles of Salmonella serovars from retail beef in Selangor, Malaysia. Front. Microbiol., 8(January): 2697.

31. Huehn, S., La Ragione, R.M., Anjum, M., Saunders, M., Woodward, M.J., Bunge, C., Helmuth, R., Hauser, E., Guerra, B., Beutlich, J., Brisabois, A., Peters, T., Svensson, L., Madajczak, G., Litrup, E., Imre, A., HerreraLeon, S., Mevius, D., Newell, D.G. and Malorny, B. (2010) Virulotyping and antimicrobial resistance typing of Salmonella enterica serovars relevant to human health in Europe. Foodborne Pathog. Dis., 7(5): 523-35.

32. Sambrook, J., Fritscgh, E.F. and Mentiates, T. (1989) Molecular Cloning. A Laboratory Manual. Vol. 3. ${ }^{2 n} \mathrm{~d}$ ed. Cold Spring Harbor Laboratory Press, New York. p55-57.

33. Osman, K.M., Moussa, I.M.I., Yousef, A.M.M., Aly, M.M., Radwan, M.I. and Alwathnani, H.A. (2010) Pathogenicity of some avian Salmonella serovars in two different animal models: SPF chickens and BALB/c mice. Environ. We Int. J. Sci. Tech., 5:65-78.

34. Bancroft, J.D. and Gamble, M. (2008) Theory and Practice of Histological Techniques. Elsevier Health Sciences, Netherlands.

35. Kalyuzhny, A.E. (2016) Immunohistochemistry: Essential Elements and Beyond. Springer, Berlin, Germany.

36. Low, L.C., Lam, B.C., Wong, W.T., Chan-Lui, W.Y. and Yeung, C.Y. (1984) Salmonella meningitis in infancy. Aust. Paediatr. J., 20(3): 225-228.

37. Anne, R.P., Vaidya, P.C., Ray, P. and Singhi, P.D. (2018) Salmonella Typhimurium meningitis in an infant presenting with recurrent meningitis. Indian J. Pediatr. 85(7): 560-562.

38. Vasquez-Lopez, M.E., Pego, R., Somoza, C., GarciaPlata, C., Rodriguez-De La Riva, P. and MoralesRedondo, R. (1998) Meningitis due to Salmonella in the neonatal period. Rev. Neurol., 27(160): 986-987.

39. Adhikary, R., Joshi, S. and Ramakrishnan, M. (2013) Salmonella Typhimurium meningitis in infancy. Indian $J$. Crit. Care Med., 17(6): 392-393.

40. Koko, J., Dufillot, D., Kani, F., Gahouma, D. and ReymondYeni, A. (1997) Salmonella meningitis in children in Libreville. Retrospective study of 9 cases. Arch. Pédiatr., 4(12): 1175-1181

41. Molyneux, E., Walsh, A., Phiri, A. and Molyneux, M. (1998) Acute bacterial meningitis in children admitted to the Queen Elizabeth central hospital, Blantyre, Malawi in 1996-97. Trop. Med. Int. Health, 3(8): 610-618.

42. Feasey, N.A., Masesa, C. and Jassi, C. (2015) Three epidemics of invasive multidrug-resistant Salmonella bloodstream infection in Blantyre, Malawi, 1998-2014. Clin. Infect. Dis., 61(4): S363-S371.

43. Wu, H.M., Huang, W.Y., Lee, M.L., Yang, A.D., Chaou, K.P. and Hsieh, L.Y. (2011) Clinical features, acute complications, and outcome of Salmonella meningitis in children under one year of age in Taiwan. BMC Infect. Dis., 11:30.

44. Owusu-Ofori, A. and Scheld, W.M. (2003) Treatment of Salmonella meningitis: Two case reports and a review of the literature. Int. J. Infect. Dis., 7(1): 53-60.

45. Wilson, R. and Feldman, R. (1981) Reported isolates of Salmonella from cerebrospinal fluid in the United States. 1968-1979. J. Infect. Dis., 143(3): 504-506.

46. McCracken, G.H. Jr., Mize, S.G. and Threlkeld, N. (1980) Intraventricular gentamicin therapy in gram-negative bacillary meningitis of infancy. Report of the second neonatal meningitis cooperative study group. Lancet, 1(8172): 787-791.

47. Bryan, J.P., Da Silva, H.R., Tavares, A., Sande, M.A. and Scheld, W.M. (1990) Etiology of and mortality from bacterial meningitis in Northeastern Brazil. Rev. Infect. Dis., 12(1): 128-135.

48. El-Sharkawy, H., Tahoun, A., El-Gohary, A.A., El-Abasy, M., El-Khayat, F., Gillespie, T., Kitade, Y., Hafez, H.M., Neubauer, H. and El-Adawy, H. (2017) Epidemiological, molecular characterization and antibiotic resistance of Salmonella enterica serovars isolated from chicken farms in Egypt. Gut Pathog., 9:8.

49. Halfaoui, Z., Menoueri, N.M. and Bendali, L.M. (2017) Serogrouping and antibiotic resistance of Escherichia coli isolated from broiler chicken with colibacillosis in center of Algeria. Vet. World, 10(7): 830-835.

50. Tacconelli, E., Sifakis, F. and Harbarth, S. (2018) Surveillance for control of antimicrobial resistance. Lancet Infect. Dis., 18(3): e99-e106.

51. Wistrand-Yuen, E., Knopp, M., Hjort, K., Koskiniemi, S., Berg, O.G. and Andersson, D.I. (2018) Evolution of highlevel resistance during low-level antibiotic exposure. Nat. Commun., 9(1): 1599.

52. Knöppel, A., Näsvall, J. and Andersson, D.I. (2017) Evolution of antibiotic resistance without antibiotic exposure. Antimicrob. Agents Chemother., 61(11): e1495-17.

53. Mendonça, E.P., de Melo, R.T. and Nalevaiko, P.C. (2019) Spread of the serotypes and antimicrobial resistance in strains of Salmonella spp. Isolated from broiler. Braz. J. Microbiol., 50(2): 515-522.

54. Herold, R., Schroten, H. and Schwerk, C. (2019) Virulence factors of meningitis-causing Bacteria: Enabling brain entry across the blood-brain barrier. Int. J. Mol. Sci., 20(21): 5393.

55. Connor, T.R., Owen, S.V. and Langridge, G. (2016) What's in a name? Species-wide whole-genome sequencing resolves invasive and noninvasive lineages of Salmonella enterica serotype paratyphi B. MBio, 7(4): e0527-16.

56. Branchu, P., Bawn, M. and Kingsley, R.A. (2018) Genome variation and molecular epidemiology of Salmonella enterica serovar Typhimurium pathovariants. Infect. Immun., 86(8): e00079-18

57. Gong, J., Wang, C., Shi, S., Bao, H., Zhu, C., Kelly, P., Zhuang, L., Lu, G., Dou, X., Wang, R., Xu, B. and Zou, J. (2016) Highly drug-resistant Salmonella enterica serovar Indiana clinical isolates recovered from broilers and poultry workers with diarrhea in China. Antimicrob. Agents Chemother., 60(3): 1943-1947.

58. Dando, S.J., Mackay-Sim, A., Norton, R., Currie, B.J., St John, J.A., Ekberg, J.A., Batzloff, M., Ulett, G.C. and Beacham, I.R. (2014) Pathogens penetrating the central nervous system: Infection pathways and the cellular and molecular mechanisms of invasion. Clin. Microbiol. Rev., 27(4): 691-726.

59. Doran, K.S., Fulde, M., Gratz, N., Kim, B.J., Nau, R., Prasadarao, N., Schubert-Unkmeir, A., Tuomanen, E.I. and Valentin-Weigand, P. (2016) Host-pathogen interactions in bacterial meningitis. Acta Neuropathol., 131(2): 185-209.

60. Wajid, M., Awan, A.B., Saleemi, M.K., Weinreich, J., Schierack, P., Sarwar, Y. and Ali, A. (2019) Multiple drug resistance and virulence profiling of Salmonella enterica serovars Typhimurium and Enteritidis from poultry farms of Faisalabad, Pakistan. Microb. Drug Resist., 25(1): 133-142.

61. Bauler, T.J., Starr, T. and Nagy, T.A. (2017) Salmonella meningitis associated with monocyte infiltration in mice. Am. J. Pathol., 87(1): 187-199. 